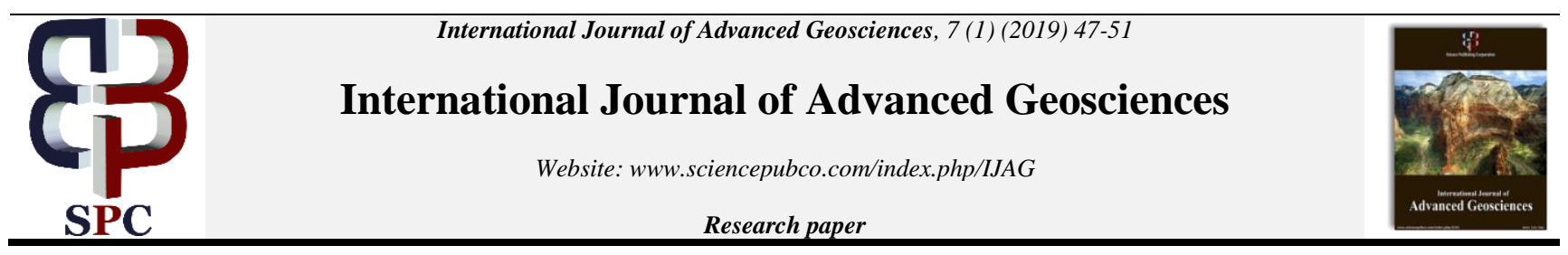

\title{
Application of groundwater transport modelling in groundwa- ter development and management: a review
}

\author{
Suvendu Kumar Sahu ${ }^{1}{ }^{*}$, Kamalesh Mondal ${ }^{1}$, Gobinath $\mathbf{M}^{1}{ }^{1}$, D. C. Jhariya ${ }^{1}$ \\ ${ }^{1}$ Department of Applied Geology National Institute of Technology Raipur Raipur 492010, Chhattisgarh, India \\ *Corresponding author E-mail: suvendukumarsahu7@gmail.com
}

\begin{abstract}
Groundwater is one of the very sensible natural resource and to protect its quality there is need of proper management system. Groundwater modelling is very advance method for the simulation, forecasting and set remediation strategy to protect the ground-water system, it is an emerging field in groundwater study. So many scientists and researchers are working on this to prepare a groundwater management strategy and to improve the efficiency of the model. For solving the different groundwater related issues, it is important to select proper model. For the accuracy of the model result, it needs to have proper idea about the model, procedure of model run and selection of model basing on the problems. There are a smaller number of modelling software like SWAT, MODFLOW, MT3DMS, RT3D, MT3D, FLUXOS, CXTFIT, FEFLOW, Retraso-Code-Bright etc. Sometimes coupled models are also preferable as per the problem. This paper based on review of the general characteristics of different transport modelling software, methodology of the model development and its application in the different issues related to groundwater development and management.
\end{abstract}

Keywords: FEMWATER; Groundwater Transport Modelling; MODFLOW; MT3DMS; RT3D.

\section{Introduction}

The moment when considering water distribution on earth, then $3 / 4$ th part of earth covered with water only, but not all these water suitable for human use. In earth very less amount of water as ground water. So groundwater is very valuable resource for human society and it needs a proper well planned management strategy. Previously population is very less and they were consuming groundwater indirectly but at present with the fast growing population water demand also increases rapidly. Extraction of groundwater enormously without proper management strategy, affects groundwater both qualitative and quantitatively. To simulate these issues a proper management strategy can construct by using groundwater modelling.

A safe management of groundwater indicates the management of both quantity and quality of groundwater because without quality even a large aquifer is not suitable for using the water. To save the groundwater quality and quantity from both natural and anthropogenic factors, groundwater modelling technique is very convenient. There are so many works have done using this groundwater modelling (Lee MS et al. 2005, Akbariyeh S et al. 2018, Wei X et al. 2018). These models give the idea about the response of aquifer to different stress and can forecast the response of the aquifer to those stress in future. Quality of water is mainly affected by excess water extraction, Fertilizers used in agricultural activity, unmanaged sewage dumping, unplanned mine waste dumping, saline water intrusion, natural contaminant source, etc. This review is about the discussion of some transport modelling software and their application in groundwater management primarily to protect the groundwater quality.

\section{Overview of groundwater transport modelling software}

There are numbers of groundwater modelling software used for the forecasting, hindcasting and also Simulation of present condition of aquifer system such as flow and transport of system. Groundwater transport modelling cannot be done by simply using transport modeling software. For transport modelling it need to couple the transport and flow model, as transport model take the output data of flow model as input. Even though there are many transport modelling software but some more useful models are SWAT, MODFLOW, MT3DMS, RT3D, MT3D, FLUXOS, CXTFIT, FEFLOW, Retraso-Code Bright.

\subsection{MODFLOW}

It is most accepted user friendly groundwater modelling software used widely and having demand among researchers and scientist. It is three dimensional finite difference groundwater flow model (McDonald and Harbaugh, 1988). Mainly used for the simulation of the groundwater flow direction, water budget, potentiometric head calculation. The parameters used to construct a model are hydraulic conductivity, transmissivity, aquifer thickness, specific yield, specific retention, recharge, boundary condition, pumping well, drainage. By 
coupled with the transport model, head data is used as input for transport model to simulate the nutrient transport (Brown PL et al. 1998, Ding F et al. 2014, Wei X et al. 2018).

\subsection{SWAT}

It is surface water assessment tool and employs one dimensional analytical routines to route the contaminated surface water to sub basin outlet through stream network and saturation zone. It simulates the surface process like uptake, runoff, surface solute transport, overland flow, lateral flow, evapotranspiration, plant growth, root zone processes etc. Some contaminant transport is simulated by using coupling SWAT-MODFLOW-RT3D model. (Wei X et al. 2018)

\subsection{MT3DMS}

This one is widely used three-dimensional transport modelling software, use for the simulation of nutrient transport processes like advection, diffusion dispersion and chemical reaction of multi nutrient species in groundwater systems. Coupled MODFLOW-MT3DMS is used in a twostep flow and transport modelling. Cell-to-cell hydraulic heads, water budget and flux are computed by the help of MODFLOW in the flow modelling and are recorded in a specially formatted file. After this the file is taken by MT3DMS and use it as primary input for the simulated area. (Babu OG et al. 2015, Vetrimurugan E et al. 2017, Akbariyeh S et al. 2018). MT3DMS is advance version of the MT3D model, available with new versions of GMS. It allows multi-species transport phenomena, supports additional solvers, and allows for parameters input of all model cell-by-cell.

\subsection{RT3D}

It is reactive transport 3d model, developed by the Battelle Pacific Northwest National Laboratory. It is a modified version of MT3DMS that utilized for multi-species reactive transport model, can simulate advection, dispersion \& chemical reaction of dissolved constituent in groundwater system by using output computed by MODFLOW. RT3D is taken in to consideration because of its ability to simulate kinetics of multiple interacting species. (Lee., M.S. et al., 2005, Wei, X., 2018,). The equation for tran sport modelling is;

$\emptyset \frac{\partial C_{k}}{\partial t}=-\frac{\partial}{\partial x_{i}}\left(\emptyset v_{i} C_{k}\right)+\frac{\partial}{\partial x_{i}}\left(\varnothing D_{i j} \frac{\partial C_{k}}{\partial x_{j}}\right)+q_{s} C_{s_{k}}-\rho_{b} \frac{\partial \bar{C}_{k}}{\partial_{t}}+\emptyset r(k=1,2, \ldots, m)$

Where.

$\mathrm{m}=$ total number of aqueous species

$\mathrm{C}_{\mathrm{k}}=$ Concentration of $\mathrm{K}^{\mathrm{th}}$ species

$\mathrm{D}_{\mathrm{ij}}=$ hydro dynamic dispersion co-efficient

$\mathrm{v}=$ average seepage velocity

$\mathrm{b}=$ bulk phase

$\emptyset=$ soil porosity

$\mathrm{q}_{\mathrm{s}}=$ volumetric flux of water representing sources and sinks of the species

$\mathrm{C}_{\mathrm{s}_{\mathrm{k}}}=$ concentration of the source or sink

$\mathrm{r}=$ rate of all reactions

$\rho_{\mathrm{b}}=$ bulk density of the porous media

$\overline{\mathrm{C}}_{\mathrm{k}}=$ concentration of the $\mathrm{k}^{\text {th }}$ species sorbet on solids

\subsection{FLUXOS}

This one is a coupled river and groundwater flow and transport model. It is combination of four codes i.e. +QeS2 (for surface water transport), MT3DMS (for groundwater transport), $2 \mathrm{dMb}$ (for surface water flow model) and MODFLOW (for groundwater flow model). Used to simulate river-groundwater interaction. (Costa D et al. 2016)

\subsection{CXTFIT}

It is one dimensional solute transport model use to estimate transport parameters and field tracer. It can simulate dual porosity problem for diffusive exchange between domains. The code FRACTRAN is used here for saturated groundwater flow and transport in fractured, porous heterogeneous ground water system. (Jorgensen., P.R. et al., 2004).

\subsection{FEFLOW}

It is an interactive finite-element simulation model for two/three dimensional horizontal and vertical, steady or transient fluid density, coupled flow, heat and mass transport modelling software. Used for both porous and fractured media. (Rajaveni SP et al. 2016).

\subsection{FEMWATER}

This is a three dimensional finite element model use for the simulation of the flow, transport or the combination of the both for the density dependent model like saline water intrusion in both saturated and unsaturated media. It calculates both horizontal and vertical extension of saline intrusion. (Lin et al. 1997).

\subsection{Retraso-code bright}

It is a coupled finite element model use for all one, two and three dimensional modelling. It is a coupled model of Code-bright (Coupled Deformation of Brine Gas and Heat Transport) use for the thermal-mechanical-hydraulic process analysis and Retraso (Reactive Transport 
of Solutes) use for reactive transport analysis. It is applicable for both liquid and gaseous phase transport (Saaltink MW 2005, Chaparro MC et al. 2017).

\section{Basic modelling procedure}

For generating the model, there are different parameters used for different model but the process of model generation is almost similar for all. The steps involve in model generation are shown in Fig. 1.

\subsection{Purpose of the study/ problem identification}

The principal procedure for model generation is proper identification of the problem. Selection of model and accuracy of model result depends on the problem identification. The problems/Objectives are mainly groundwater flow, contaminant transport, heat and solute transport, saltwater intrusion, fixing a proper pumping strategy, locating position for establishment of recharge and pumping well, impact of different natural and anthropogenic activities on aquifer. (Lin et al. 1997, Brown PL et al. 1998, Lee MS et al. 2005, Ding F et al. 2014, Akbariyeh S et al. 2018, Wei X et al. 2018).

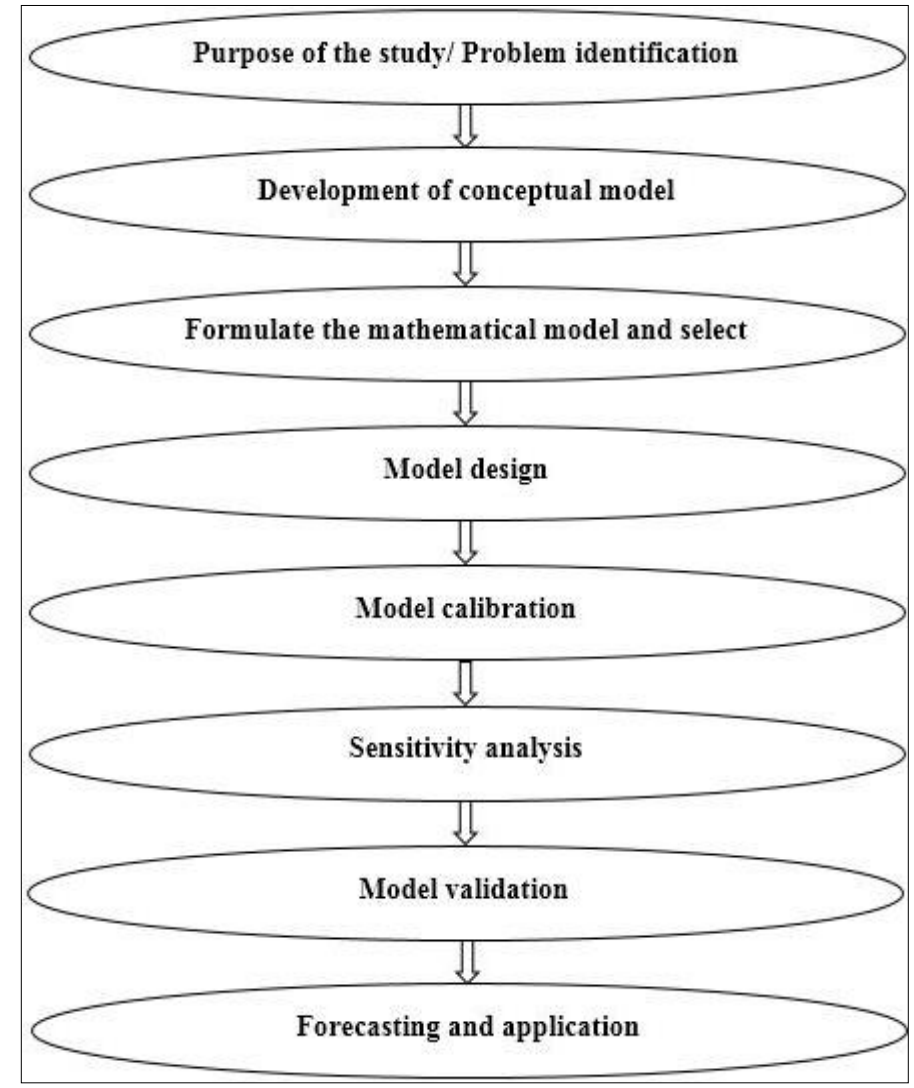

Fig. 1: Work Flow for Model Development.

\subsection{Development of conceptual model}

After the identification of the problem of that particular study area, development of conceptual model by the available field data is the next step. Conceptual model is the systematic representation of the field characteristics, which is constructed on the basis of available value of the different parameters such as elevation of area, aquifer thickness, recharge, discharge, conductivity, transitivity, water head, boundary condition, stratigraphy of the area (Brown PL et al. 1998, Lee MS et al. 2005, Elango L et al. 2012, Rajaveni SP et al. 2016). After assigning the different parameter value, the total study area is need to divide in to grids, as the modelling is depends on each grid element and their parameter value.

\subsection{Formulate the mathematical model and select modelling code}

For the model run it need to transfer the conceptual model in to numerical model, and derive some mathematical equation for the model simulation. By seeing the objective and involved parameters certain modelling code is need to select.

\subsection{Model design}

Designing the numerical model on the basis of conceptual model involves Implementing boundaries in a numerical model, FD grid and FE mesh generation, model layers assigning, input of sources, sinks and all parameters. The main purpose is to simplify the complex aquifer system (Anderson P \& Woessner WW 2015). 


\subsection{Model calibration}

The main objective of the model calibration is to increase the accuracy of the model result by methods like trial and error method. Here values of different parameters are changed up to certain limit to get the result or field condition as similar to actual field scenario. Calibration is carried out to reduce the model error. Accuracy of the calibrated model can be calculated by the evaluation of mean error, mean absolute error and root mean square error. (Elango L et al. 2012, Anderson P \& Woessner WW 2015).

\subsection{Sensitivity analysis}

Sensitivity analysis is performed to find out the most sensitive parameters for the aquifer which affect the aquifer system by minor change in it (Anderson P \& Woessner WW 2015). The main objective is forecasting of the area by identifying the most sensible parameters and prepared some management strategy to prevent the negative effect of changing parameters on groundwater system (Elango L et al. 2012, Rajaveni SP et al. 2016).

\subsection{Model validation}

Model validation indicates, to what extent that model is correct by comparing with real time data and therefore capable of making accurate (valid) forecast. Recalibrate and validate the model according to the availability of new data from the observed field condition (Anderson P \& Woessner WW 2015).

\subsection{Forecasting and application}

After model development it need to run the prepared model and forecasting condition the aquifer system and prepare the aquifer management strategy to prevent different upcoming issues.

\section{Application of transport modelling in groundwater management}

\subsection{Simulation of agricultural effect and its solution}

Different fertilizers are highly soluble and mobile in water system and is transported by the process of advection, dispersion and it causes other contaminants species like selenite and sulfate in water system. For $\mathrm{NO}_{3}$ transport both surface water and ground water system are related. Groundwater is contaminated by leaching of fertilizer through soil profile and transported through the saturated zone and finally it delivered to river and streams by groundwater discharge. Remediation strategies/methods should adopt by seeing the scenarios of changes in land use and climatic patterns. After developing the model by coupled MODFLOW-MT3DMS, it can be helpful in determine the agricultural crop pattern, amount of fertilizer, pattern of irrigation, time for the particular crop production to prevent or minimize the groundwater contamination due to the agricultural activity (Lee MS et al. 2005, Vetrimurugan E et al. 2017, Akbariyeh S et al. 2018, Wei X et al. 2018).

\subsection{Spatial control on groundwater quality}

Due to heavy rainfall, soluble nutrients in agricultural field can leach out through zone of saturation and due to more hydrostatic pressure contaminated groundwater discharge to stream in high rate causes transport of nutrients to surface water system. It varies from time to time, so modelling system helps to simulate this time wise contamination variation (Wei $\mathrm{X}$ et al. 2018).

\subsection{Simulation of surface and groundwater interaction}

By FLUXOS coupled model we can simulate the surface and groundwater interaction. Both contaminants transport from aquifer to river and river to aquifer can be modelled. Along with the condition of surface water due to over extraction of groundwater can be modelled. By knowing the problems of surface-groundwater interaction we can adopt some proper management strategy to overcome that issue for sustainable use of surface and groundwater (Costa D et al. 2016, Wei X et al. 2018).

\subsection{Selection of site for the application of bio-remedies}

This model (RT3D) used to simulate the source and transformation of nitrogen compound in saturated zone. Also, it helps to decide the site for establishing bioremediation trenches for reduce or remove the nitrogen contaminants from groundwater system (Lee MS et al. 2005).

\subsection{Simulation of contaminant in highly fractured terrain}

DFMD (Discrete fracture/matrix diffusion) numerical modelling by FRACTRAN is most appropriate method for transport modelling in fractured- heterogeneous terrain. It estimates the potential of subsurface water pollution with the transport rate of that tracer. Also interpret the contamination rate with respect to time (season), flow rate, pores and fracture geometry and contamination related to influent and effluent flow. (Jorgensen PR et al. 2004).

\subsection{Simulation of water contamination by industries and their solution}

Simulate the effect of metal, non-metal and radioactive element industries on quality and quantity of groundwater of that area along with classifying the area in to different zone as per TDS concentration and decide the site for establishing industries and locate the area for disposal of industrial waste (Brown PL et al. 1998, Elango L et al. 2012, Babu OG et al. 2015). 


\subsection{Saline water intrusion}

Forecasting of the sea level rise \& fall, chloride concentration, groundwater head in different part of the coastal aquifer along with the extension of saline water intrusion. Most convenient process to identify the region of salt water intrusion and classifying the site horizontally and vertically as per intrusion potential. By FEFLOW, SEAWAT, FEMWATER model we can forecast extent of seawater intrusion in upcoming years. By modelling we can recommend the pumping rate and site for the establishment of pumping well and recharge well. To prevent the saline water intrusion, we can decide the proper managed aquifer recharge (MAR) through groundwater modelling. The possible method of MAR for in this area are construction of check dam and increase the crest of existing check dam for enhance the groundwater recharge and reduce the concentration of chloride (Lin et al. 1997, Ding F et al. 2014, Rajaveni SP et al. 2016).

\subsection{Contaminant assessment in bore well}

In the bore well the interaction of cement, water flux and host rock unit controls the water quality and quantity along with the hydrological properties of host. By the process of dissolution and diffusion Portland get diffused from the cement and make the water hyper-alkaline and some minerals are get precipitated on the host surface and reduce its porosity. This can be simulated by the help of Retraso-Code Bright (Chaparro MC et al. 2017).

\section{Conclusion}

This paper is a review on different groundwater transport modelling application in the groundwater quality related problems. Groundwater modelling method is a new and very appropriate method to prepare a strategy for the groundwater quality and quantity management. It able to estimate the response of aquifer to different hydrological parameters and also can forecast the parameter's impact on the groundwater system. Different groundwater issues like impact of agriculture, industrial activities, over exploitation of groundwater, saline water intrusion, waste dump, subsurface petroleum transport along with the natural causes affect the quality and quantity of the groundwater system directly or indirectly. So, to interpret their causes, impact assessment in present and in future along with deciding mitigation process is main objective of the groundwater modelling. Groundwater modelling is very advance method for the transport and flow modelling but not accurate, because by model it is not possible to create the actual field condition as in nature there is possibility of very complex filed condition. Though groundwater modelling is very effective and helps to create the present and future condition of water system so we need to depend on it also need to improve the software to match the real field condition.

\section{References}

[1] Akbariyeh S, Hunt SB, Snow D, Li X, Tang Z, Li Y, 2018. Three-dimensional modeling of Nitrate-N transport in Vadose Zone: Roles of soil heterogeneity and groundwater flux. Journal of Contaminant Hydrology. Pp. 15-25 https://doi.org/10.1016/j.jconhyd.2018.02.005.

[2] Anderson MP, Woessner WW, Hunt RJ (2015) Applied groundwater modelling simulation of flow and advective transport. Edn. $2^{\text {nd }}$, Elesvier. DOI: https://www.elsevier.com/books/applied-groundwater-modeling/anderson/978-0-08-091638-5.

[3] Brown PL, Guerin M, Hankin SI, Lowson RT (1998) Ura nium and other contaminant migration in groundwater at a tropical Australian Uranium Mine. Journal of Contaminant Hydrology. Pp. 295-303. https://doi.org/10.1016/S0169-7722(98)00129-6.

[4] Babu OG, Saravanan R, Sashikkumar MC, and Pitchaikani S (2015) Assessment of Groundwater Vulnerability to Pollution Using Modflow. The Asian Review of Civil Engineering, pp. 20-27.DOI:http://www.trp.org.in/wp-content/uploads/2015/10/TARCE-Vol.4-No.1-Jan-June-2015-pp.2027.pdf.

[5] Costa D, Burlando P, Liong SY (2016) Coupling spatially distributed river and groundwater transport models to investigate contaminant dynamics at river corridor scales. Elsevier, pp. 91-110. https://doi.org/10.1016/j.envsoft.2016.09.009.

[6] Chaparro MC, Saaltink MW, Soler JM (2017) Reactive transport modelling of cement-groundwater-rock interaction at the Grimsel Test Site. Physics and Chemistry of the Earth. Pp. 1-13. https://doi.org/10.1016/j.pce.2017.05.006.

[7] Ding F, Yamashita T, Lee HS, and Pan J (2014) A modelling study of seawater intrusion in the Liao doing bay coastal plain, china. Journal of Marine Science and Technology, Vol. 22, No. 2, pp. 103-115.

[8] Elango L, Brindha K, Kalpana L, Sunny F, Nair RN and Murugan R (2012) Groundwater flow and radionuclide decay-chain transport modelling around a proposed uranium tailings pond in India. Hydrogeology Journal, pp. 797-812. https://doi.org/10.1007/s10040-012-0834-6.

[9] Jørgensen PR, Helstrup T, Urup J and Seifert D (2004) Modeling of non-reactive solute transport in fractured clayey till during variable flow rate and time. Journal of Contaminant Hydrology, pp. 193-216. https://doi.org/10.1016/S0169-7722(03)00146-3.

[10] Lin HJ, Rechards DR, Talbot CA, Yeh GT, Cheng JR, Cheng HP, Jones NL (1997) A Three-dimensional finite element computer model for simulating density- dependent flow and transport in variable saturated media. Version 3.1. U.S Army Engg. Research and development center, Vicksburg, M.S. DOI: https://apps.dtic.mil/dtic/tr/fulltext/u2/a327967.pdf.

[11] Lee MS, Lee KK, Hyun Y, Clement TP and Hamilton D (2005) Nitrogen transformation and transport modeling in groundwater aquifers. Ecological Modelling, pp. 143-159. https://doi.org/10.1016/j.ecolmodel.2005.07.013.

[12] McDonald MG, Harbaugh AW (1988) A modular three-dimensional finite difference groundwater flow model, US Geological survey techniques of water resources of water resource investigations, book-6, Chap. A1, US Geological survey, Open file report. DOI: https://pubs.usgs.gov/twri/twri6a1/pdf/TWRI_6-A1.pdf.

[13] Rajaveni SP, Nair IS and Elango L (2016) Evaluation of Impact of Climate Change on Seawater Intrusion in a Coastal Aquifer by Finite Element Modelling. Journal of Climate Change, Vol. 2, pp. 111-118. https://doi.org/10.3233/JCC-160022.

[14] Saaltink MW, Ayora C, Olivella S, (2005) User's guide for Retraso Code Bright (RCB). DOI: https://h2ogeo.upc.edu/software/retraso/ManualRCB.pdf.

[15] Vetrimurugan E, Senthilkumar M, and Elango L (2017) Solute transport modelling for assessing the duration of river flow to improve the groundwater quality in an intensively irrigated deltaic region. Int. J. Environ. Sci. Technol. https://doi.org/10.1007/s13762-016-1211-0.

[16] Wei X, Bailey RT, Records RM, Wible TC and Arabi M (2018) Comprehensive Simulation of Nitrate Transport in Coupled Surface Subsurface Hydrologic Systems using the linked SWAT-MODFLOW-RT3D model. Environmental Modelling and Software, pp. 1-33. https://doi.org/10.1016/j.envsoft.2018.06.012. 